\title{
Differential Stress, Strain Rate, and Temperatures of Mylonitization in the Ruby Mountains, Nevada: Implications for the Rate and Duration of Uplift
}

\author{
Bradley R. HACKER, ${ }^{1}$ AN Yin, and John M. Christie \\ Department of Earth and Space Sciences, University of California, Los Angeles \\ ARTHUR W. SNOKE \\ Department of Geology and Geophysics, University of Wyoming, Laramie
}

\begin{abstract}
Knowledge of the magnitude of the differential stress during the formation of mylonitic rocks provides constraints on mechanical and thermal models for the exhumation of the metamorphosed footwalls of major low-angle detachment faults. We have analyzed the differential flow stress during the mylonitization of quartzose rocks in the Ruby Mountains, Nevada, using grain-size piezometers and kinetic laws for grain growth. Quartziles from mylonitic shear zones in Lamoille Canyon and Secret Creek gorge have grain sizes of $91-151 \mu \mathrm{m}$ and $42-64 \mu \mathrm{m}$, respectively. The peak temperature during mylonitization was $630^{\circ} \pm 50^{\circ} \mathrm{C}$, and analysis of grain-growth kinetics indicates that mylonitization continued during cooling to temperatures $5450^{\circ} \mathrm{C}$. Quartz grain-size piezometers suggest that the mylonitization occurred under differential stresses $\left(\sigma_{1}-\sigma_{3}\right)$ of 38-64 MPa, or maximum shear stresses of 19-32 MPa. Extrapolation of quartzite flow laws indicates that the mylonitization occurred at strain rates between $10^{-10}$ and $10^{-13} \mathrm{~s}^{-1}$; arguments presented in the paper suggest that the likely range of strain rates is $10^{-11}$ to $10^{-12} \mathrm{~s}^{-1}$. These strain rates are compatible with displacement rates of the order of $23 \mathrm{~mm} \mathrm{yr}^{-1}$ along a $1.5 \cdot \mathrm{km}$-thick simple shear zone. Such a shear zone dipping $15^{\circ}$ would produce an uplift rate of $5.8 \mathrm{~km} \mathrm{~m} . \mathrm{y}^{-1}$ and a horizontal extension rate of $22 \mathrm{~km} \mathrm{~m} \cdot \mathrm{y}^{-1}$. This uplift rate indicates that midcrustal mylonitic rocks could have been lifted up along a 1.5-km-thick simple shear zone dipping $15^{\circ}$ in $2.6 \mathrm{~m} . \mathrm{y}$.
\end{abstract}

\section{INTRODUCTION}

Dynamic processes within ductilely deformed middle continental crust played an important role in mid-Tertiary core complex extension in the North American Cordillera [e.g., Coney and Harms, 1984]. Knowledge of the state of stress in the middle crust during the extension is fundamental to understanding the physics of those processes. First, the differential stress provides a direct constraint on any mechanical modelling of crustal deformation. It can also be used, in conjunction with the temperature history of the rocks and experimental flow laws, to infer the strain rate during the development of ductile shear zones, which are common features in Cordilleran core complexes [e.g., Crittenden et al., 1980; Frost and Martin, 1982; Snoke and Lush, 1984; Dovis et al., 1986].

The core complexes and associated detachment fault systems have been intensively studied in the past decade [e.g., Crittenden et al., 1980; Frost and Martin, 1982; Lister and Snoke, 1984; Coney and Harms, 1984; Davis and Lister, 1988]. A growing body of field data has allowed the formulation of conceptual models to explain the development of detachment fault systems [e.g., Wernicke, 1981, 1985; Davis et al., 1986]. It is generally believed that upper crustal detachment faults (regional low-angle normal faults) were kinematically linked with ductile simple shear zones in the

\footnotetext{
Tow at Department of Geology, Stanford University, Stanford California.

Copyright 1990 by the American Geophysical Union.
}

Paper number 89JB03512.

0148-0227/90/89JB-03512\$05.00 middle crust [e.g., Davis et al., 1986]. The ductilely deformed midcrustal rocks were lifted up along the footwalls of the detachment faults to Earth's surface. Although the geometrical evolution of brittle detachment fault systems and the kinematics of the associated ductile shear zones have been studied by numerous geologists, little is known about the differential stress and strain rate during the evolution of these deeper shear zones.

The purpose of this paper is to use theoretically derived and experimentally calibrated microstructural piezometry of quartz to infer the differential stress during the mylonitization of quartzose rocks along a shear zone in the Ruby Mountains core complex. The strain rates, and rates of extension and uplift during the development of the shear zone are then calculated by applying quartzite flow laws at the estimated stresses and metamorphic temperatures.

\section{Experimental Basis for Piezometry}

Piezometry is the measurement of differential stress. At temperatures where metals recrystallize during deformation, the recrystallized grain size [Luton and Sellars, 1969; Glover and Sellars, 1973; Bromley and Sellars, 1973], subgrain size [Dunning et al., 1982], and dislocation density [Bird et al., 1969] vary systematically with the steady state flow stress and are independent of temperature and total strain (beyond a small critical strain). Experimental studies on olivine [Goetze and Kohlstedt, 1973; Kohlstedt and Goetze, 1974; Kohlstedt et al., 1976; Post, 1977; Durham et al., 1977; Mercier et al., 1977; Ross et al., 1980a; Zeuch, 1983; Zeuch and Green, 1984], calcite [Goetze and Kohlstedt, 1977; Friedman and Higgs, 1981], ice [Burg et al., 1986], halite [Friedman et al., 1981; Handin et al., 1986], and quartz [Mercier et al., 1977; McCormick, 1977; Mainprice, 1981; Koch, 1983] single 
crystals and polycrystalline aggregates have also demonstrated quantitative relationships between differential stress and dislocation density, subgrain size, and recrystallized grain size. Furthermore, experiments on quartzite and novaculite by Koch [1983] showed that the dislocation density, grain size, and spacing of deformation lamellae are independent of strain rate, water content, finite strain, temperature, and initial grain size. These experimentally established relationships between differential stress and microstructures have been used by the above authors and others [Kirby and Wegner, 1979; Briegel and Goetze, 1978; Weathers et al., 1979; Kohlstedt et al., 1979; Avé Lallement et al., 1980; Christie and Ord, 1980; Kohlstedt and Weathers, 1980; Mercier, 1980; Ross et al., 1980b; Etheridge and Wilkie, 1981; Ross, 1983; Kappmeyer and Wiltschko, 1984; Karato, 1984; Ord and Christie, 1984; Avé Lallement, 1985] to infer differential stresses in the mantle and the crust.

\section{Geology of the Ruby Mountains}

The Ruby Mountains core complex, northeastern Nevada (Figure 1) is commonly cited as a classic example of a metamorphic core complex [Crittenden et al., 1980], and extensive structural, geochronological, and geothermobarometric studies have been conducted on the

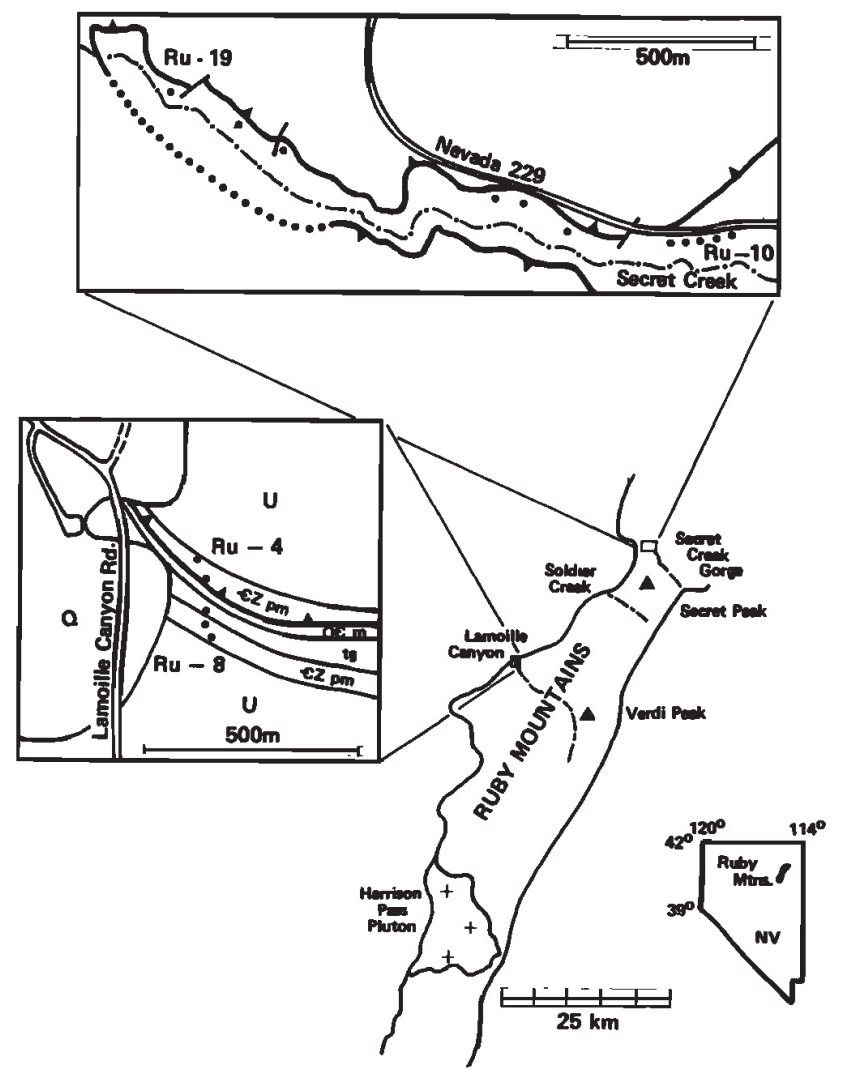

Fig. 1. Location map. The rock units in the Lamoille Canyon inset are Q, undivided Quatemary rocks; CZpm, Prospect Mountain Quartzite; $\mathrm{OCm}$, marble of Verdi Peak; tg, gneiss of Thorpe Creek; and $U$, undifferentiated rocks. The fault shown is the premylonitic Ogilvie thrust fault [see Snoke and Howard, 1984, Figure 5]. The fault in the Secret Creek gorge inset is a synmylonitic to postmylonitic low-angle normal fault separating quartzite, migmatitic schist, and orthogneiss of Late Proterozoic to Cambrian age from overlying plates, including the Horse Creek allochthon [see Snoke and Howard, 1984, Figure 17]. mylonitic rocks exposed in the lower plate below the Ruby Mountains detachment fault (see Snoke and Miller [1988] for a review]. The migmatitic core of the range consists chiefly of amphibolite-facies Upper Proterozoic to lower Paleozoic miogeosynclinal rocks intruded by granitic rocks [e.g., Howard, 1971; Howard et al., 1979; Snoke, 1980]. Low-grade miogeosynclinal metasedimentary rocks and Tertiary sedimentary and volcanic rocks structurally overlie the migmatitic core as fault-bounded slices [e.g., Snoke, 1980; Snoke and Lush, 1984]. Locally pervasive mylonitic fabrics overprint both the high-grade rocks of the migmatitic core and the fault-bounded lower grade rocks; abundant microstructural kinematic indicators indicate that the sense of shear was topto-the-west-northwest throughout most of the range [Lister and Snoke, 1984; Snoke and Miller, 1988]. Numerous brittle structures superposed on the mylonitic rocks suggest that the metamorphic core rocks were unroofed by regional extension of the upper crust along low-angle normal faults that rooted into more distributed shear zones at mid-crustal depths [Snoke, 1980; Snoke and Lush, 1984; Dallmeyer et al., 1986; Snoke and Miller, 1988].

Extensive ${ }^{40} \mathrm{Ar} /{ }^{39} \mathrm{Ar}, \mathrm{K} / \mathrm{Ar}, \mathrm{U} / \mathrm{Pb}$, and fission track data provide constraints on the thermal evolution of the Ruby Mountains. In the Late Jurassic to Cretaceous, amphibolitefacies metamorphism was accompanied by plutonism and regional deformation [e.g., Kistler et al., 1981; Dallmeyer et al., 1986; Snoke and Miller, 1988]. The mylonitic rocks formed later, perhaps during a single, widespread protracted event or during multiple spatially or temporally distinct events. $\mathrm{U} / \mathrm{Pb}$ dating of zircons from mylonitic and nonmylonitic plutonic rocks provides the best constraints on the age of mylonitization [Wright and Snoke, 1986]. Mylonitic orthogneisses in the Ruby Mountains have crystallization ages of $32 \pm 1$ (two-mica granite orthogneiss of

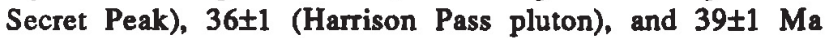
(granodiorite orthogneiss of Horse Creek), and the nonmylonitic part of the Harrison Pass pluton has a crystallization age of $36 \pm 1 \mathrm{Ma}$ [Wright and Snoke, 1986]. Hence mylonitic deformation has occurred since $32 \mathrm{Ma}$, but the age of the onset of mylonitization is unconstrained. Specific estimates of the temperature and pressure during mylonitization, determined from garnet-biotite-muscoviteplagioclase thermobarometry, are $630 \pm 50^{\circ} \mathrm{C}$ and $400 \pm 100 \mathrm{MPa}$ [Hurlow, 1988; H. Hurlow, personal communication, 1989].

The ${ }^{40} \mathrm{Ar} /{ }^{39} \mathrm{Ar}$ plateau ages of homblende and biotite indicate that rocks from Secret Creek gorge and adjacent areas (Figure 1) probably cooled from $500^{\circ} \pm 25^{\circ} \mathrm{C}$ at circa $45 \mathrm{Ma}\left({ }^{40} \mathrm{Ar}\right.$ blocking temperature of hornblende [Harrison, 1982]) to $300^{\circ} \pm 25^{\circ} \mathrm{C}$ $\left({ }^{40} \mathrm{Ar}\right.$ blocking temperature of biotite [Harrison and McDougall, 1985]) at circa $22 \mathrm{Ma}$ [Dallmeyer et al., 1986]; this implies a minimum cooling rate of $7^{\circ}-11^{\circ} \mathrm{C} \mathrm{m} . \mathrm{y}^{-1}$. Similar data from the Soldier Creek and Lamoille Canyon areas (Figure 1) indicate cooling rates of $15^{\circ}-25^{\circ} \mathrm{C} \mathrm{m} . \mathrm{y}^{-1}$ between 32 and $22 \mathrm{Ma}$, and $17^{\circ}-28^{\circ} \mathrm{C} \mathrm{m} . \mathrm{y}^{-1}$ between 30 and $21 \mathrm{Ma}$, respectively. Fission track data indicate that the detachment zone and rocks of the upper part of the mylonitic zone throughout the range cooled to less than $70^{\circ} \mathrm{C}$ by $22 \mathrm{Ma}$ [Dokka et al., 1986]. The ${ }^{40} \mathrm{Ar} /{ }^{39} \mathrm{Ar}$ and fission track data together imply that the rocks from Secret Creek gorge cooled from $500^{\circ} \pm 25^{\circ} \mathrm{C}$ to $<70^{\circ} \mathrm{C}$ at rates greater than $18^{\circ}-20^{\circ} \mathrm{C} \mathrm{m} \cdot \mathrm{y}^{-1}$ over a $23-\mathrm{m} . \mathrm{y}$. period, and the rocks from the Soldier Creek and Lamoille Canyon areas cooled faster than $40^{\circ}-46^{\circ} \mathrm{C}$ m.y. ${ }^{-1}$ over 10 m.y. and $51^{\circ}-57^{\circ} \mathrm{C}$ m.y..$^{-1}$ over 8 m.y., respectively. Basin and Range normal faulting began in the 
Ruby Mountains sometime since $15 \mathrm{Ma}$ [Snoke and Lush, Secret Creek Gorge

1984).

\section{PROCEDURE}

Samples for this study were collected from the mouth of Lamoille Canyon (field trip stop 1 of Snoke and Howard [1984]) and from Secret Creek gorge (stop 12 of Snoke and Howard [1984]). Both areas are along the western flank of the Ruby Mountains (Figure 1) where the mylonitic zone is especially well developed [Snoke and Lush, 1984].

\section{Lamoille Canyon}

The westem end of Lamoille Canyon contains exposures of the mylonitic zone that forms a carapace above the highergrade core of the range. This mylonitic zone is at least $1.5-2$ $\mathrm{km}$ thick and can be traced along the west flank of the range for about $100 \mathrm{~km}$ [Valasek et al., 1989]. Sedimentary rocks within the mylonitic zone in this area have been attenuated to $5 \%$ of their thickness outside of the zone [Snoke and Howard, 1984]. We collected five samples along a $300-\mathrm{m}$-long north-south transect at approximately $115^{\circ} 28^{\prime}$ and $40^{\circ} 41.5^{\prime}$, about $300 \mathrm{~m}$ east of the Lamoille Canyon road (Figure 1). The transect includes probable Mesozoic granite gneiss, OrdovicianCambrian calc-silicate rocks of Verdi Peak, the Cambrian and Late Proterozoic Prospect Mountain Quartzite, and the gamettwo-mica granite orthogneiss of Thorpe Creek. All the samples we collected are of Prospect Mountain Quartzite or quartzose layers in the orthogneiss of Thorpe Creek.

The samples are all strongly foliated quartzose mylonites with up to $5 \%$ muscovite and/or biotite and $5 \%$ plagioclase, generally segregated in thin layers defining a compositional foliation. They have been termed S-C mylonites by Lister and Snoke [1984], the S (schistosite) being a planar structure defined by the shape anisotropy of finely recrystallized quartz and $\mathrm{C}$ (cisaillement) the compositional layering defined by the mica and plagioclase crystals. The mica crystals are anhedral and lozenge- or fish-shaped. Plagioclase porphyroclasts are anhedral and augen-shaped with internal fractures and deformation bands. The $S$ foliation is inclined at $-20^{\circ}$ to the compositional interlayers (C). The quartz grains have a strong lattice preferred orientation, as indicated by the uniformity of colors produced by a gypsum plate; examples are illustrated by Snoke [1980, Figure 10] and Lister and Snoke [1984, Figure 15].

Samples $\mathrm{Ru}-4, \mathrm{Ru}-5$, and $\mathrm{Ru}-6$ show bimodal grain-size distribution with a few relatively large, flattened relict grains, surrounded by smaller recrystallized grains of uniform size dating from the mylonitic deformation. The relict grains are generally elongate parallel to the foliation (S), with minumum dimensions $>0.5 \times 2.0 \mathrm{~mm}$, indicating that the premylonitic protolith was coarse grained $(\gg 1.0 \mathrm{~mm})$. They show extensive undulatory extinction of the "blocky" type, defined by unbent subgrains separated by relatively high-angle subgrain boundaries. This is a well-recovered substructure. The recrystallized grains, by contrast, show little or no undulatory extinction. Their grain boundaries range from somewhat serrated (specimen Ru-7, Figure 2a), indicating grain boundary migration during or after the dynamic recrystallization that accompanied mylonitization, to straight (specimen Ru-8, Figure $2 b$ ), suggesting postmylonitic grain growth. Samples $\mathrm{Ru}-7$ and Ru-8 have a unimodal grain size distribution, but the presence of subgrain structure in a few grains suggests that they may be relict grains.
Secret Creek gorge contains fault slices of variably mylonitic Late Precambrian to lower Paleozoic metasedimentary rocks, middle to upper Paleozoic sedimentary rocks, and Miocene sedimentary and volcanic rocks separated by low-angle normal faults [Snoke and Howard, 1984]. In this area the transition from an early mylonitic fabric to later brittle deformation structures is well displayed. Ten samples were collected along a 1500 -m-long east-west transect along the south side of Nevada highway 229 (Figure 1). The samples were all collected within $10 \mathrm{~m}$ of the low-angle fault contact that separates a lower plate of mylonitic interlayered impure quartzite, migmatitic schist and orthogneiss from the overlying carbonate-rich Horse Creek allochthon.

All the samples are quartz-rich mylonites with thin layers containing muscovite or biotite $(0-5 \%)$ or plagioclase (1$10 \%$ ). Several samples (Ru-11, Ru-12, and $R u-17$ ) show "ribbon" textures, with large quartz grains, greatly elongated parallel to the compositional layering (C), separated by finegrained recrystallized grains (Figure $2 c$ ). The linear intercept measurements (Table 1) do not include the large relict grains. In these samples the amount of recrystallization varies from $\sim 20 \%$ in sample $\mathrm{Ru}-17$, with relict grain dimensions parallel to the lineation of $0.3 \times 6.0 \mathrm{~mm}$, to $80 \%$ in sample Ru-12, with relict grain dimensions of $0.2 \times 15.0 \mathrm{~mm}$. The elongation of the small recrystallized grains defines a weak foliation (S) that (measured in sections parallel to the lineation and normal to the foliation) is parallel to $\mathrm{C}$ in samples Ru-12, Ru-16, Ru-18, and $\mathrm{Ru}-19$, and inclined to $\mathrm{C}$ at angles of $15^{\circ}, 20^{\circ}$, and $27^{\circ}$ in samples $\mathrm{Ru}-10, \mathrm{Ru}-11$, and $\mathrm{Ru}-15$, respectively. Plagioclase is present as anhedral or augen-shaped, cracked porphyroclasts.

The grain-boundary configurations and internal structures of quartz in the rocks from Secret Creek gorge differ somewhat from those from Lamoille Canyon. The "ribbon" grains show, in addition to some blocky subgrain structure, continuous undulatory extinction or bending. The recrystallized grains, which are less than half the size of those in the Lamoille Canyon mylonites, also show slight, continuous undulatory extinction (less than $10^{\circ}$ and commonly less than $5^{\circ}$ of bending in a single grain), without optically visible subgrains in most of the samples (e.g., Figure $2 d$ ). Undulatory extinction is essentially absent in samples Ru-12 and Ru-18. This indicates considerably less recovery during dynamic recrystallization, or more prolonged plastic deformation after recrystallization, than in the Lamoille Canyon mylonites. The grain boundaries are commonly irregular or sutured, indicating grain boundary migration during or after deformation. In general, the textures of the Secret Creek gorge mylonites suggest deformation and recrystallization at lower temperatures, with less postmylonitic grain growth than in the Lamoille Canyon mylonites. The large size of the quartz ribbons and of the mica and plagioclase porphyroclasts indicates a coarse-grained ( $\geq 2 \mathrm{~mm}$ ) premylonitic protolith for most of these rocks.

\section{Grain Size Determination}

The recrystallized grain sizes were measured by the method of Ord and Christie [1984]. Two 1-inch round polished wafers were cut from each sample. Both wafers were cut perpendicular to the foliation; one was cut parallel to the lineation and the other was cut orthogonal to the lineation. Each was etched with $40 \%$ ammonium bifluoride for $15 \mathrm{~min}$ to reveal grain boundaries, but not low angle sub-grain boundaries [Wegner 

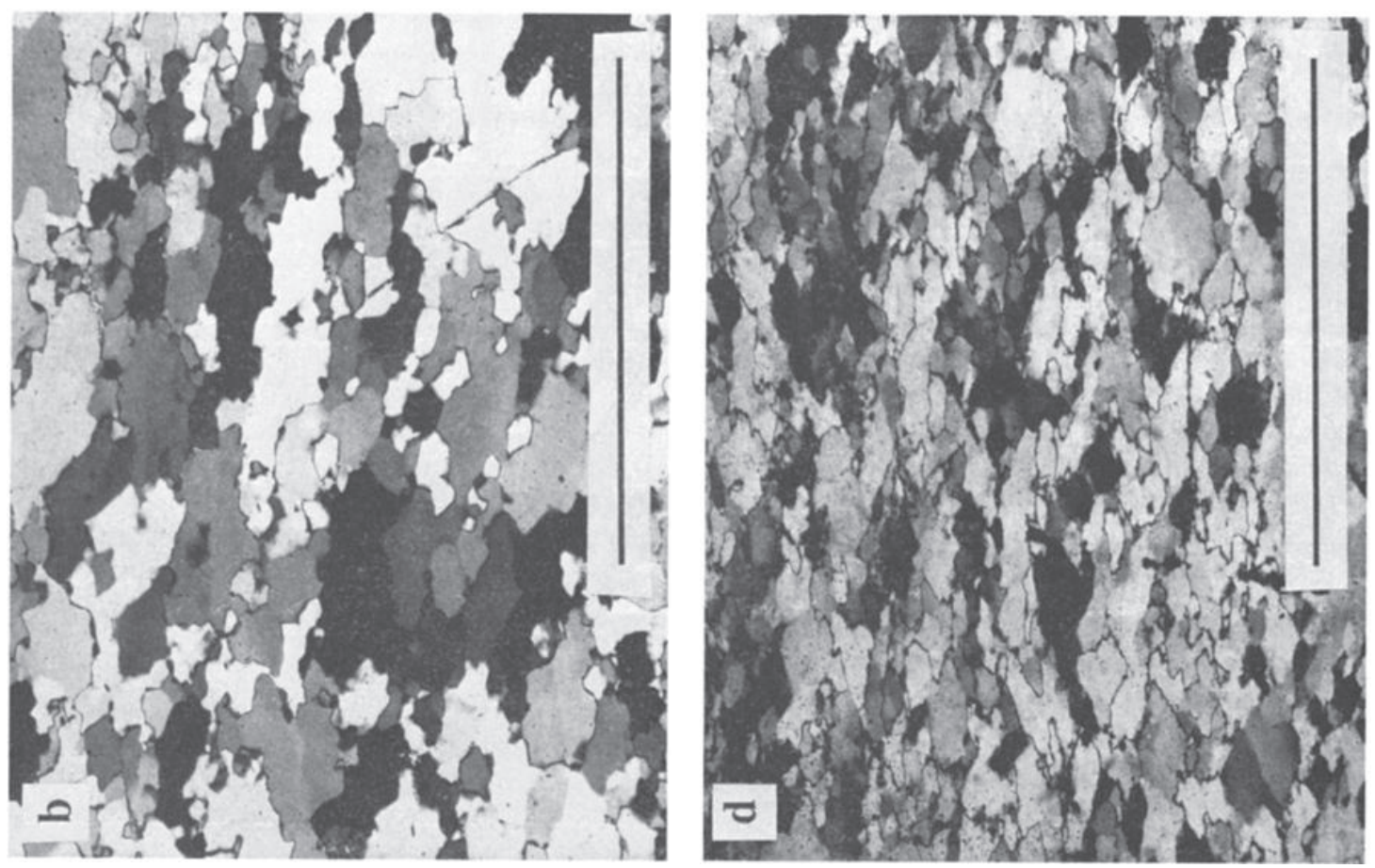

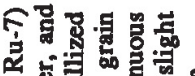

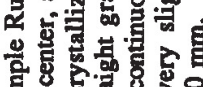

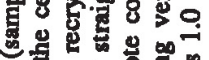

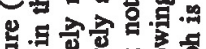

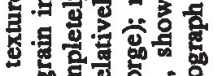
可

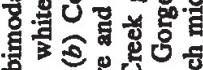

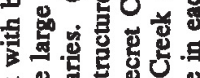
恄的

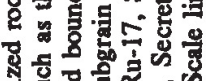

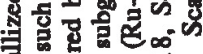
S

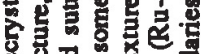

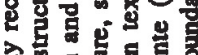

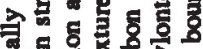
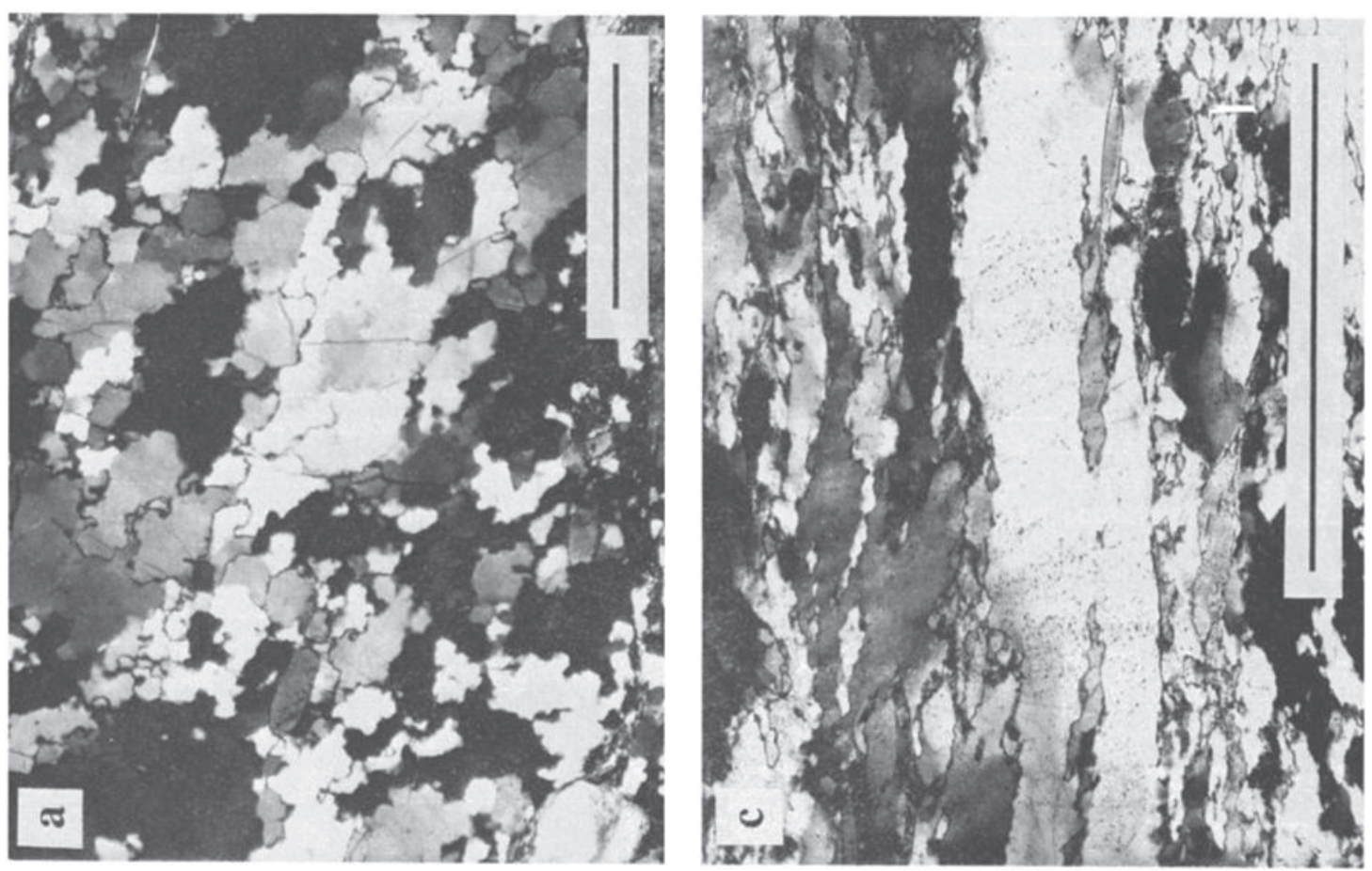

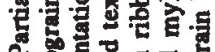

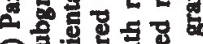

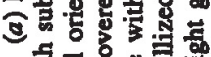

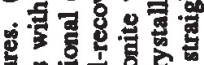
.

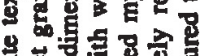

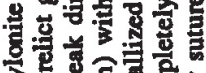

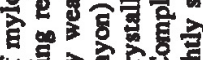

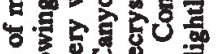
을 를

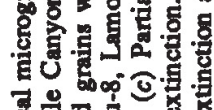

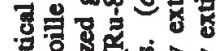

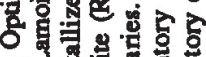

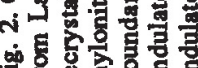

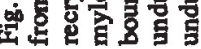


TABLE 1. Number of Grains Counted, Geometric Mean Grain Aspect Ratios, and Geometric Mean Grain Size

\begin{tabular}{lrcc}
\hline Sample & $N$ & Aspect Ratios & $\begin{array}{c}\text { Grain Size } D, \\
\mu m\end{array}$ \\
\hline Ru-4 & 584 & $1.4: 1.0: 0.7$ & $147 \pm 46$ \\
Ru-5 & 470 & $1.2: 1.0: 0.8$ & $91 \pm 17$ \\
Ru-6 & 579 & $1.4: 1.0: 0.8$ & $146 \pm 38$ \\
Ru-7 & 561 & $1.0: 1.0: 1.0$ & $151 \pm 20$ \\
Ru-8 & 631 & $1.5: 1.0: 0.8$ & $138 \pm 43$ \\
Ru-10 & 852 & $1.1: 1.0: 0.9$ & $49 \pm 5$ \\
Ru-11 & 1046 & $1.3: 1.0: 0.7$ & $42 \pm 11$ \\
Ru-12 & 673 & $1.4: 1.0: 0.8$ & $64 \pm 18$ \\
Ru-13 & 789 & $1.1: 1.0: 0.9$ & $54 \pm 8$ \\
Ru-14 & 725 & $1.3: 1.0: 0.8$ & $59 \pm 13$ \\
Ru-15 & 730 & $1.0: 1.0: 0.9$ & $58 \pm 7$ \\
Ru-16 & 737 & $1.3: 1.0: 0.9$ & $58 \pm 10$ \\
Ru-17 & 792 & $1.3: 1.0: 0.9$ & $53 \pm 8$ \\
Ru-18 & 732 & $1.4: 1.0: 0.7$ & $60 \pm 17$ \\
Ru-19 & 788 & $1.5: 1.0: 0.9$ & $54 \pm 14$ \\
\hline
\end{tabular}

and Christie, 1983]. Etched samples were coated in a vacuum with aluminum to enhance reflectivity and then photographed with a reflected light microscope at magnifications of 25-100 times. Grain size estimates were made from mean linear intercepts [Smith and Guttman, 1953] of 500-1000 grains per sample. To investigate the grain-shape anisotropy, measurements of grain boundary intercepts per unit length were made parallel and perpendicular to the trace of the foliation in each of the orthogonal sections. Five sets of measurements (of 25-50 grains) were made in each direction on each polished sample, and combined to yield a geometric mean grain size. Only pure quartz layers were measured, because impurities (e.g., mica and feldspar) interfere with grain-boundary migration and generally produce a smaller stable grain size [Christie and Ord, 1980]. Areas with bimodal grain size were avoided.

For each sample listed in Table 1, the mean grain size quoted for a single sample is the geometric mean of 20 inverse mean linear intercepts (each of $\mathbf{2 5 - 5 0}$ grains) and is not the geometric mean that would be obtained by measuring grains individually. Ranalli [1984] has shown that the geometric mean is appropriate for lognormal distributions, and grain sizes in rocks are typically lognormally distributed. The distribution of inverse mean linear intercept values (20 for each sample) are shown in Figure 3. Many of the distributions are not lognormal: this is a reflection of the ellipsoidal shape of the grains and the distribution of the absolute grain sizes. The uncertainties in the grain sizes are given as standard deviations from the geometric mean grain sizes and are all roughly 20 $30 \%$ of the geometric means.

\section{Results}

\section{Grain Sizes}

All five samples from Lamoille Canyon have grain sizes of 91-151 $\mu \mathrm{m}$; grain sizes from four of the five samples are tightly clustered between 138 and $151 \mu \mathrm{m}$ (Table 1 and Figure 3). The recrystallized grain shapes are approximately ellipsoidal, with axial ratios as extreme as 1.5:1.0:0.8. Grain sizes of all 10 samples from Secret Creek gorge span the range 42-64 $\mu \mathrm{m}$; eight of the 10 are within the range $49-60 \mu \mathrm{m}$ (Table
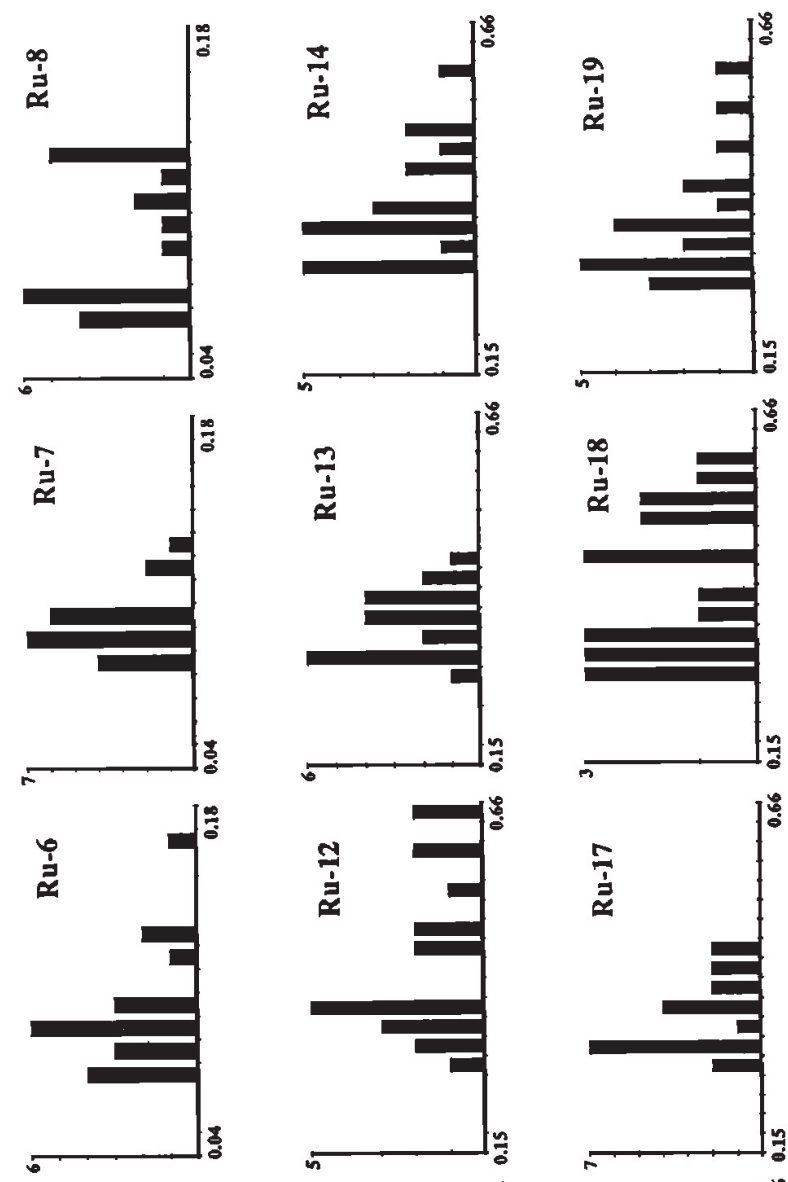

:
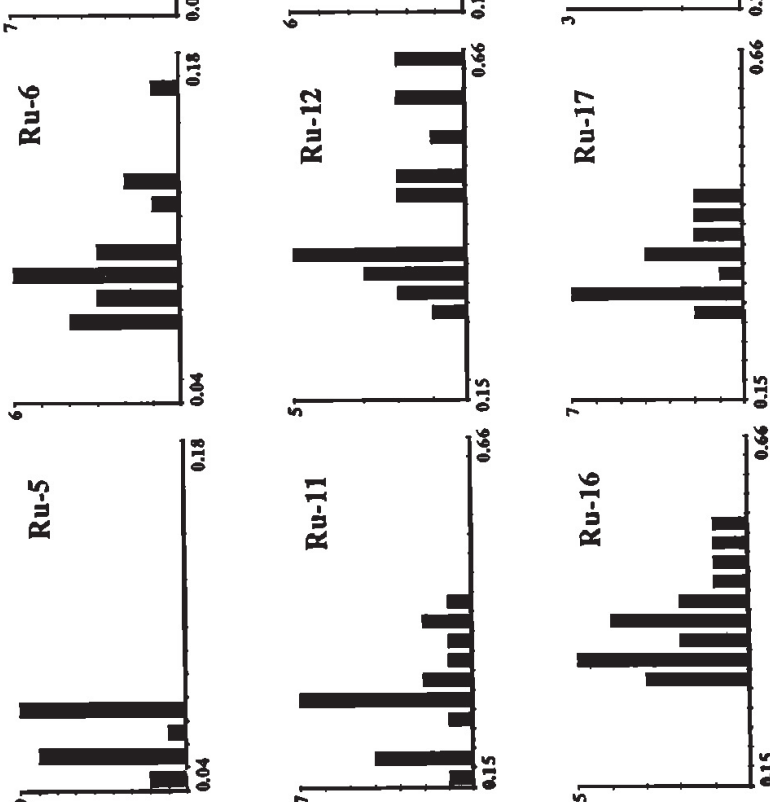

$\stackrel{5}{\circ}$
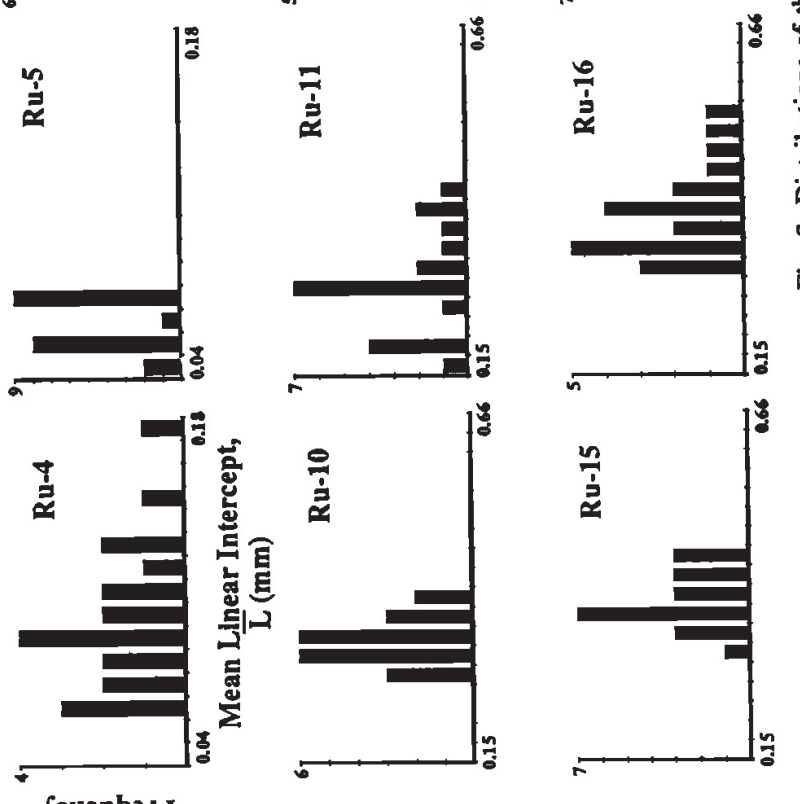
1). Grain-shape ellipsoids range from 1.0:1.0:0.9 to $1.5: 1.0: 0.9$. There is no systematic correlation between the mean grain size, the standard deviation of grain size, or the aspect ratios of quartz crystals, and the amount of mica and/or plagioclase in the rock. Because postdeformational annealing may have caused these grains to grow, the measured grain sizes are probably larger than the grain sizes developed during the mylonitization.

The rocks collected from Lamoille Canyon are roughly twice as coarse as those from Secret Creek gorge (Table 1). This implies that either the differential stress or the thermal history was different at the two localities. Homblende cooling ages $\left({ }^{40} \mathrm{Ar} /{ }^{39} \mathrm{Ar}\right)$ [Dallmeyer et al., 1986] and field relations [Howard et al., 1979] both indicate that the rocks exposed in Lamoille Canyon represent deeper structural levels than rocks in Secret Creek gorge. As demonstrated below, the inferred grain-growth histories of rocks from these two areas are compatible with this conclusion.

\section{Differential Stress During Mylonitization}

We used the recrystallized-grain-size piezometers of Twiss [1977, 1980], Mercier et al. [1977], and Koch [1983] (Table 2), to calculate the differential stress for each sample using our measured grain sizes (Table 3). Mercier et al.'s [1977] piezometer is less precise because the grain-size measurements were made of 1-25 $\mu \mathrm{m}$ diameter grains in standard 30- $\mu \mathrm{m}$-thick sections using transmitted light microscopy. We prefer the recrystallized-grain-size piezometer of Koch [1983], because it is based on combined data from experiments on "wet" and "dry" quartzite, flint, and novaculite, deformed over a wide range of pressures, temperatures, and strain rates, in solid-medium [Koch et al., 1989] and gas-medium apparatus [Mainprice, 1981]. Further, Koch [1983] incorporated uncertainties in his and Mainprice's [1981] experimental measurements in his piezometer calibration; consequently, this piezometer yields uncertainties for the calculated differential stresses that include both the experimental calibration error and the standard deviations of the grain-size measurements. Moreover, we used the same grain-size measurement technique that Koch used, so that our grain sizes are directly comparable to Koch's.

Differential stresses for the rocks from Lamoille Canyon range from 7 to $17 \mathrm{MPa}$, with four of the five samples between

TABLE 2. Parameters for Recrystallized Grain Size-Flow Stress Relationships for Quartzites

\begin{tabular}{|c|c|c|}
\hline Parameter & \multicolumn{2}{|l|}{ Definition } \\
\hline$\sigma$ & \multicolumn{2}{|l|}{$(D / b)^{1 / R}$} \\
\hline$D$ & \multicolumn{2}{|l|}{$b \sigma^{R}$} \\
\hline $\boldsymbol{\sigma}$ & \multicolumn{2}{|l|}{ differential stress, $\mathrm{MPa}$} \\
\hline$b$ & \multicolumn{2}{|l|}{ constant, $\mu \mathrm{m} \mathrm{MPa}-R$} \\
\hline$D$ & \multicolumn{2}{|l|}{ grain size, $\mu \mathrm{m}$} \\
\hline $\boldsymbol{R}$ & \multicolumn{2}{|l|}{ constant } \\
\hline Source & $b, \mu \mathrm{m} \mathrm{MPa}-R$ & $\boldsymbol{R}$ \\
\hline Twiss $[1977,1980]$ & $1.45 \times 10^{4}$ & -1.47 \\
\hline Mercier et al. [1977] & $4.07 \times 10^{3}$ & -1.4 \\
\hline Koch [1983]* & $4.90_{-0.43}^{+0.47} \times 10^{2}$ & $-0.59 \pm 0.2$ \\
\hline
\end{tabular}

"Includes data from six experiments by Mainprice [1981]
TABLE 3. Calculated Differential Stresses, MPa

\begin{tabular}{|c|c|c|c|c|}
\hline Sample & $\begin{array}{c}\text { Grain Size } \\
\bar{D}, \mu \mathrm{m}\end{array}$ & $\begin{array}{c}\text { Twiss } \\
{[1977,1980]}\end{array}$ & $\begin{array}{c}\text { Mercier et al. } \\
\text { [1977] }\end{array}$ & $\begin{array}{l}\text { Koch" } \\
{[1983]}\end{array}$ \\
\hline \multicolumn{5}{|c|}{ Lamoille Canyon } \\
\hline $\mathbf{R u}-4$ & $147 \pm 46$ & $23_{-4}^{+6}$ & $11_{-2}^{+3}$ & $8_{-3-4}^{+6+11}$ \\
\hline Ru-5 & $91 \pm 17$ & $31_{-3}^{+5}$ & $15_{-2}^{+3}$ & $17_{-4-7}^{+7+15}$ \\
\hline $\mathbf{R u}-6$ & $146 \pm 38$ & $23_{-2}^{+5}$ & $11_{-2}^{+2}$ & $8_{-3-4}^{+5+9}$ \\
\hline Ru-7 & $151 \pm 20$ & $22_{-1}^{+3}$ & $11_{-1}^{+1}$ & $\begin{array}{l}7_{-1-2}^{+2}+5 \\
-1\end{array}$ \\
\hline $\mathbf{R u}-8$ & $138 \pm 43$ & $24_{-4}^{+7}$ & $11_{-2}^{+4}$ & $\begin{array}{l}9+7+12 \\
-4-5\end{array}$ \\
\hline \multicolumn{5}{|c|}{ Secret Creek Gorge } \\
\hline Ru-10 & $49 \pm 5$ & $48_{-3}^{+4}$ & $23_{-1}^{+2}$ & $\begin{array}{c}49+10+31 \\
-7-17\end{array}$ \\
\hline $\mathbf{R u}-11$ & $42 \pm 11$ & $53_{-8}^{+13}$ & $26_{.4}^{+7}$ & $\begin{array}{c}64_{-21-31}^{+42+83} \\
\end{array}$ \\
\hline Ru-12 & $64 \pm 18$ & $40_{-6}^{+10}$ & $19_{-3}^{+6}$ & $\begin{array}{l}31+23+43 \\
-10-15\end{array}$ \\
\hline Ru-13 & $54 \pm 8$ & $45_{-4}^{+5}$ & $22_{-2}^{+3}$ & $\begin{array}{c}42+12+32 \\
-9-16\end{array}$ \\
\hline Ru-14 & $59 \pm 13$ & $42_{-5}^{+8}$ & $21_{-3}^{+4}$ & $\begin{array}{c}36+18+38 \\
-10-16\end{array}$ \\
\hline Ru-15 & $58 \pm 7$ & $43_{-3}^{+4}$ & $21_{-2}^{+2}$ & $\begin{array}{c}37^{+9}+25 \\
-7-13\end{array}$ \\
\hline $\mathrm{Ru}-16$ & $58 \pm 10$ & $43_{-5}^{+6}$ & $21_{-2}^{+3}$ & $\begin{array}{c}37_{-9}^{+14+31} \\
\text { - } 15\end{array}$ \\
\hline Ru-17 & $53 \pm 8$ & $45^{+6}$ & $22_{-2}^{+3}$ & $\begin{array}{l}43+14+34 \\
-9-17\end{array}$ \\
\hline Ru-18 & $60 \pm 17$ & $42+10$ & $20_{-3}^{+6}$ & $\begin{array}{l}35+26+48 \\
-12-17\end{array}$ \\
\hline Ru-19 & $54 \pm 14$ & $45_{-7}^{+10}$ & $22_{-3}^{+5}$ & $\begin{array}{l}+27+52 \\
42-14-20\end{array}$ \\
\hline
\end{tabular}

The uncertainties given are derived from (1) the standard deviation of the grain size (first or only $+/$ - numbers), and from (2) the uncertainty of the grain size and the uncertainty of the piezometer calibration (second +/- numbers; for Koch only).

"Includes data from six experiments by Mainprice [1981].

7 and $9 \mathrm{MPa}$. Differential stresses for the rocks from Secret Creek gorge range from 31 to $64 \mathrm{MPa}$, with eight of the 10 samples between 35 and $49 \mathrm{MPa}$. Note that the uncertainties of these values are in some cases as large as the values themselves. Because the grain size may have increased during postdeformational annealing, these calculated differential stresses are lower limits to the stress during the mylonitization. The effect of annealing will be considered quantitatively below.

\section{Discussion}

\section{Postdeformational Annealing}

Grain sizes that develop during steady state deformation can increase during post-deformational annealing (after removal of deviatoric stress), particularly if the annealing period is lengthy or if the annealing begins at high temperatures [Twiss, 1977]. Invariably, grains are larger after annealing than they were during deformation, and the larger, annealed grain size leads to an underestimate of the actual flow stress (see Table 3). The kinetics of grain growth in quartzite as a function of pressure and temperature have been determined [Tullis and Yund, 1982; Pierce and Christie, 1987], and the effect of grain growth during annealing can be evaluated. 
TABLE 4. Experimentally Determined Parameters for Kinetics of Grain Growth in Flint and Novaculite

\begin{tabular}{cl}
\hline Parameter & Definition \\
\hline $\bar{L}$ & $\left(c t+\bar{L}_{\mathrm{O}}^{2}\right)^{1 / 2}$ \\
$c$ & $c_{0} \exp \left(-\left(H+P V^{*}\right) / R T\right), \mathrm{m}^{2} \mathrm{~s}^{-1}$ \\
$\bar{L}$ & final grain size, $\mathrm{m}$ \\
$c_{0}$ & preexponential constant, $7.47 \times 10^{-4} \mathrm{~m}^{2} \mathrm{~s}^{-1}$ \\
$t$ & time, 8 \\
$\bar{L}_{\mathrm{O}}$ & initial grain size, $\mathrm{m}$ \\
$H$ & activation enthalpy, 281 kJ/mol \\
$P$ & pressure, GPa; we chose a pressurc of $0.4 \mathrm{GPa}$ for \\
& our calculations, based on H. Hurlow (personal \\
$V^{*}$ & communication, 1989) \\
$R$ & activation volume, $-1.86 \times 10^{-8} \mathrm{~m}^{3} \mathrm{~mol}^{-1}$ \\
$T$ & gas constant, 8.314 J $\mathrm{K}^{-1} \mathrm{~mol}^{-1}$ \\
\hline
\end{tabular}

From Pierce [1987].

Estimates of the peak temperature and pressure during mylonitization, determined from gamet-biotite-muscoviteplagioclase thermobarometry, are $630^{\circ} \pm 50^{\circ} \mathrm{C}$ and $400 \pm 100$ $\mathrm{MPa}$ [Hurlow, 1988; H. Hurlow, personal communication, 1989]. Consideration of the grain-growth kinetics of quartz aggregates, however, indicates that mylonitization must have continued to lower temperatures. The average grain sizes of the Lamoille Canyon and Secret Creek gorge rocks are 146 and 57 $\mu \mathrm{m}$, respectively. From the kinetic laws for the grain growth of quartz (Table 4) [Tullis and Yund, 1982; Pierce and Christie [1987], we calculated by numerical integration the graingrowth history for grains with a final diameter of 146 and 57 $\mathrm{\mu m}$ developed during fixed cooling rates (Figure 4). Figure 4 shows several grain growth paths for cooling from different temperatures at a linear rate of $54^{\circ} \mathrm{C} \mathrm{m.y.}{ }^{-1}$ (the minimum
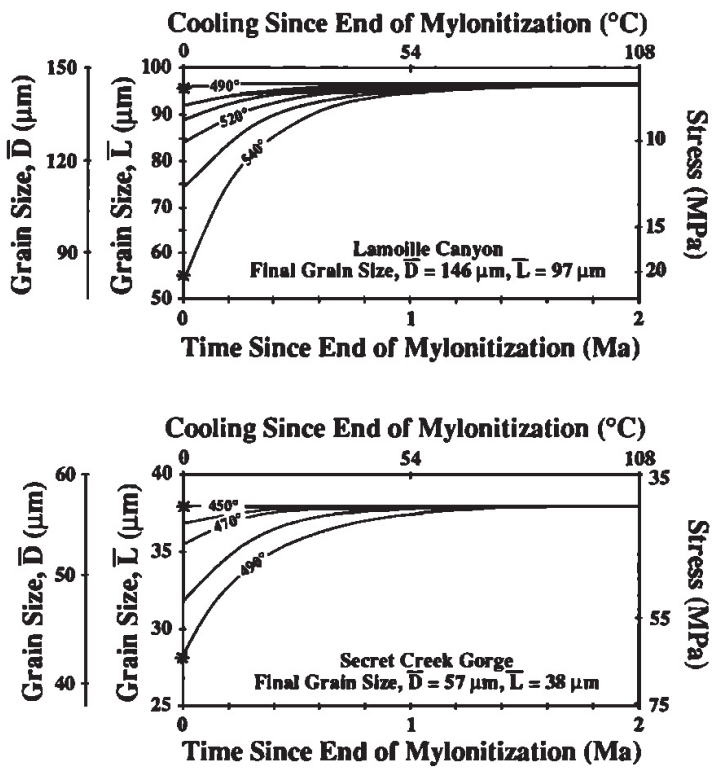

Fig. 4. Grain growth paths for rocks that cool at a constant rate of $54^{\circ} \mathrm{C}$ m.y. ${ }^{-1}$ and reach final grain sizes of $\bar{D}=57$ and $146 \mu \mathrm{m}$. This assumption of constant cooling rate is a more precise constraint than assuming exponential conductive cooling, because heat is not lost as rapidly initially. Asterisks refer to the temperatures and grain sizes on which the calculations in Table 6 are based. cooling rate given by ${ }^{40} \mathrm{Ar} /{ }^{39} \mathrm{Ar}$ and fission track data for the mylonitic rocks in Lamoille Canyon, as explained earlier). The paths were calculated by assuming that steady state mylonitization produced a grain size controlled by the differential stress; then the mylonitization ceased instantaneously, and was followed by annealing during hydrostatic cooling. Although this assumption oversimplifies the stress and temperature history, data for more sophisticated modelling are not presently available. Grains of $146-\mu \mathrm{m}$ diameter can form during annealing from any initial grain size smaller than $146 \mu \mathrm{m}$. At $5490^{\circ} \mathrm{C}, 146-\mu \mathrm{m}$ grains do not grow; this temperature is symbolized as $T_{e}$, the "annealing blocking temperature," for this grain size and cooling rate. During cooling from $540^{\circ} \mathrm{C}$, grains that were initially $83 \mu \mathrm{m}$ grow to a final grain size of $146 \mu \mathrm{m}$. At temperatures $2550^{\circ} \mathrm{C}$, grains rapidly grow to more than $146 \mu \mathrm{m}$, regardless of the initial grain size. This places an upper limit $\left(T_{\max }\right)$ on the temperature at the end of mylonitization of the rocks in Lamoille Canyon of $540^{\circ} \mathrm{C}$, based on grain-growth kinetics. Thus $81 \mu \mathrm{m}$ is the minimum grain size that could have resulted from mylonitization at $540^{\circ} \mathrm{C}$, corresponding to a differential stress of $21 \mathrm{MPa}$ (Figure 4).

Similar reasoning indicates that $T_{\alpha}=450^{\circ} \mathrm{C}$ and $T_{\max }=500^{\circ} \mathrm{C}$ for the mylonitic rocks in Secret Creek gorge with a final grain size of $57 \mu \mathrm{m}$. Grains of $57-\mu \mathrm{m}$ diameter can form during annealing from any initial grain size smaller than $57 \mu \mathrm{m}$. At $\leq 450^{\circ} \mathrm{C}, 57-\mu \mathrm{m}$ grains do not grow, thus $T_{a}=450^{\circ} \mathrm{C}$ for this grain size and cooling rate. During cooling from $490^{\circ} \mathrm{C}$, grains that were initially $43 \mu \mathrm{m}$ grow to a final grain size of $57 \mu \mathrm{m}$. At temperatures $2500^{\circ} \mathrm{C}$. grains rapidly grow to more than 57 $\mu \mathrm{m}$, regardless of the initial grain size. This places an upper limit $\left(T_{\max }\right)$ on the temperature at the end of mylonitization of the rocks in Secret Creek gorge of $490^{\circ} \mathrm{C}$, based on graingrowth kinetics. Thus $42 \mu \mathrm{m}$ is the minimum grain size that could have resulted from mylonitization at $500^{\circ} \mathrm{C}$, corresponding to a differential stress of $64 \mathrm{MPa}$ (Figure 4).

Let us now consider the constraints available on the temperature $(T)$ and differential stress during the deformation of the quartzose mylonites in the Ruby Mountains. As discussed in the preceding paragraph, grain-growth calculations show that temperatures higher than $T_{\max }$ result in grain growth that is too rapid to produce the observed grain sizes (Figure 4), leaving two possible temperature ranges: either $T_{\max }>T>T_{a}$ or $T<T_{a}$. If $T_{\max }>T>T_{a}$, then postdeformational grain growth has occurred, and the grain size and inferred differential stress during mylonitization can be read from Figure 4 (maximum values of 21 and $64 \mathrm{MPa}$ ). If $T<T_{a}$, however, the grain size measured is equal to the grain size during mylonitization, and hence the differential stress can be inferred from the measured grain size. Our calculations do not treat the case where mylonitization may have continued during cooling to lower temperatures where the rate of dynamic recrystallization was not fast enough to permit the grain size to equilibrate to changes in differential stress.

\section{Strain Rates During Mylonitization}

Once the differential stress has been determined, it can be combined with temperature estimates to determine the strain rate during mylonitization, by using "flow laws," or stresstemperature-strain rate constitutive relations. Flow laws are derived from laboratory experiments and in some cases it may be justified to extrapolate them to geologic conditions. If the natural deformation occurs at steady state conditions by the 
TABLE 5. Experimentally Determined Parameters for Power Law Creep Constitutive Equations for Quartzites

\begin{tabular}{|c|c|c|c|c|c|c|c|}
\hline Parameter & \multicolumn{7}{|l|}{ Definition } \\
\hline$\hat{\epsilon}$ & \multicolumn{7}{|c|}{$A \sigma^{n} \exp (-H / R T)$} \\
\hline$e$ & \multicolumn{7}{|c|}{ strain rate, $\mathrm{s}^{-1}$} \\
\hline$A$ & \multicolumn{7}{|c|}{ preexponential constant, $\mathrm{MPa}^{-1} \mathrm{~s}^{-1}$} \\
\hline$\sigma$ & \multicolumn{7}{|c|}{ differential stress, $\mathrm{MPa}$} \\
\hline$H$ & \multicolumn{7}{|c|}{ activation enthalpy, $\mathrm{kJ} \mathrm{mol}^{-1}$} \\
\hline $\boldsymbol{R}$ & \multicolumn{7}{|c|}{ gas constant, $8.314 \mathrm{~J} \mathrm{~K}^{-1} \mathrm{~mol}^{-1}$} \\
\hline$T$ & \multicolumn{7}{|c|}{ temperature, $\mathbf{K}$} \\
\hline \multirow{2}{*}{\multicolumn{2}{|c|}{ Reference }} & $A$ & $\boldsymbol{H}$ & $n$ & Quartzite & $\mathrm{\% H}_{2} \mathrm{O}$ & No. \\
\hline & & $\operatorname{MPan}^{-1} \mathrm{~s}^{-1}$ & 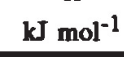 & & & & \\
\hline \multicolumn{2}{|c|}{ Shelton and Tullis [1981] } & $1.26_{-0.16^{+0.19} \times 10^{-3}}$ & 168 & 2.0 & Heavitree & 0 & 11 \\
\hline \multicolumn{2}{|c|}{ Hansen [1982] } & $3.16 \times 10^{-1}$ & 174 & 1.9 & Quadrant & 0.3 & $?$ \\
\hline \multicolumn{2}{|c|}{ Hansen and Carter [1982] } & $3.47 \times 10^{-5}$ & 123 & 1.9 & Quadrant & 0 & $?$ \\
\hline \multicolumn{2}{|c|}{ Koch [1983] } & $1.1_{-0.58}^{+1.2} \times 10^{-7}$ & $134 \pm 32$ & $2.7 \pm 0.2$ & Simpson & 0 & 19 \\
\hline \multicolumn{2}{|c|}{ Koch [1983] } & $5.05 \pm 0.006 \times 10^{-6}$ & $145 \pm 17$ & $2.6 \pm 0.15$ & Simpson & talc & 24 \\
\hline \multicolumn{2}{|c|}{ Jaoul et al. [1984] } & $5.3 \times 10^{-3}$ & $146 \pm 4$ & $1.5 \pm 0.5$ & Heavitree & 0.28 & 1 \\
\hline \multicolumn{2}{|c|}{ Kronenberg and Tullis $[1984]^{\dagger}$} & $1.58 \times 10^{-5}$ & $134 \pm 10$ & $2.6 \pm 0.3$ & $\begin{array}{c}\text { Heavitree and } \\
\text { novaculite }\end{array}$ & 0.4 & 5 \\
\hline
\end{tabular}

Quartzite, name of the rock on which the measurements were made; Kronenberg and Tullis [1984] used both Heavitree Quartzite and Arkansas novaculite. $\% \mathrm{H}_{2} \mathrm{O}$, amount of water added to the samples; talc indicates experiments in which the samples were surrounded by dehydrating talc. $\mathrm{No}_{\text {, }}$ number of samples on which measurements were made.

Includes data from eight experiments by Heard and Carter [1968].

† Preexponential constant from Kirby and Kronenberg [1987]

same mechanisms that operated during the experiments, then the constitutive relations can be used to predict one of the variables, temperature, stress, or strain rate, if the other two variables are known [Poirier, 1985]. Flow laws for steady state dislocation creep of quartzite are listed in Table 5. We did not include flow laws for vacuum-dried samples, because the presence of biotite and muscovite indicates that the natural samples were probably not deformed under anhydrous conditions. We have also excluded rheological data from experiments on novaculite and flint. None of the sets of experiments from which the flow laws were derived were ideal. All were done in solid-medium apparatus, which can not measure stress as accurately as can gas apparatus. Kronenberg and Tullis' [1984] and Jooul et al.'s [1984] experimental samples were encapsulated in platinum, which affects the stress measurements during the experiments. Further, their rheological data come from creep experiments on five or fewer samples. Koch et al.'s [1989] experiments were done with copper or copper and talc confining media, which are tstronger than the salt confining medium used in some of the other experiments. Although experiments have shown that the rheological behavior of quartz is affected by pressure, impurities such as $\mathrm{Na}$ [Jaoul, 1984], water content [Jaoul et al., 1984; Kronenberg and Tullis, 1984], and the $\alpha / \beta$ transition [Linker and Kirby, 1981; Ross et al., 1983], none of these effects can yet be extrapolated quantitatively to natural conditions.

We calculated the strain rates (Table 6) that the quartzite flow laws (Table 5) predict for several temperatures $\left(T_{\max }, T_{a}\right.$, and $400^{\circ} \mathrm{C}$ ) using the differential stresses (Table 3 ) derived from the observed grain sizes and the grain growth calculations above. At temperatures between $T_{\max }$ and $T_{a}$ the predicted strain rates for the rocks from Lamoille Canyon are in the range $10^{-9}$ to $10^{-14} \mathrm{~s}^{-1}$, and those for rocks from Secret Creek gorge are $10^{-9}$ to $10^{-12} \mathrm{~s}^{-1}$ at these temperatures. At a lower temperature, $400^{\circ} \mathrm{C}$, strain rates are one order of magnitude slower. The strain rates derived from the experiments of Koch et al. [1989] are the slowest and yield the most conservative extrapolations. Even with the maximum uncertainty (including grain-size measurement errors, piezometercalibration errors, and flow-law calibration errors), strain rates of $10^{-13} \mathrm{~s}^{-1}$ or faster are predicted for the mylonitic rocks from Secret Creek gorge.

\section{Implications for the Rate and Duration of Uplift}

If the thickness of the mylonitic shear zone that produced the mylonitic rocks is known, from the strain rate we can calculate the displacement rate across the shear zone. The mylonitic zone within the Ruby Mountains has a total thickness of 1.5-2 km [Valasek et al., 1989]. However, field relationships in Secret Creek gorge indicate that as the mylonitic rocks cooled, strain localization occurred, and the fault zone became progressively narrower [Snoke and Lush, 1984]. The rocks that we sampled from Secret Creek gorge represent some unknown, presumably intermediate step in the transition from a thick, homogeneously deforming zone to a thinner shear zone with localized subzones of concentrated deformation. The effective thickness of the shear zone at the final stage of mylonitization could have been considerably less than $2 \mathrm{~km}$.

Assuming that the deformation history within the shear zone 
TABLE 7. Shear Zone Parallel Displacement Rates

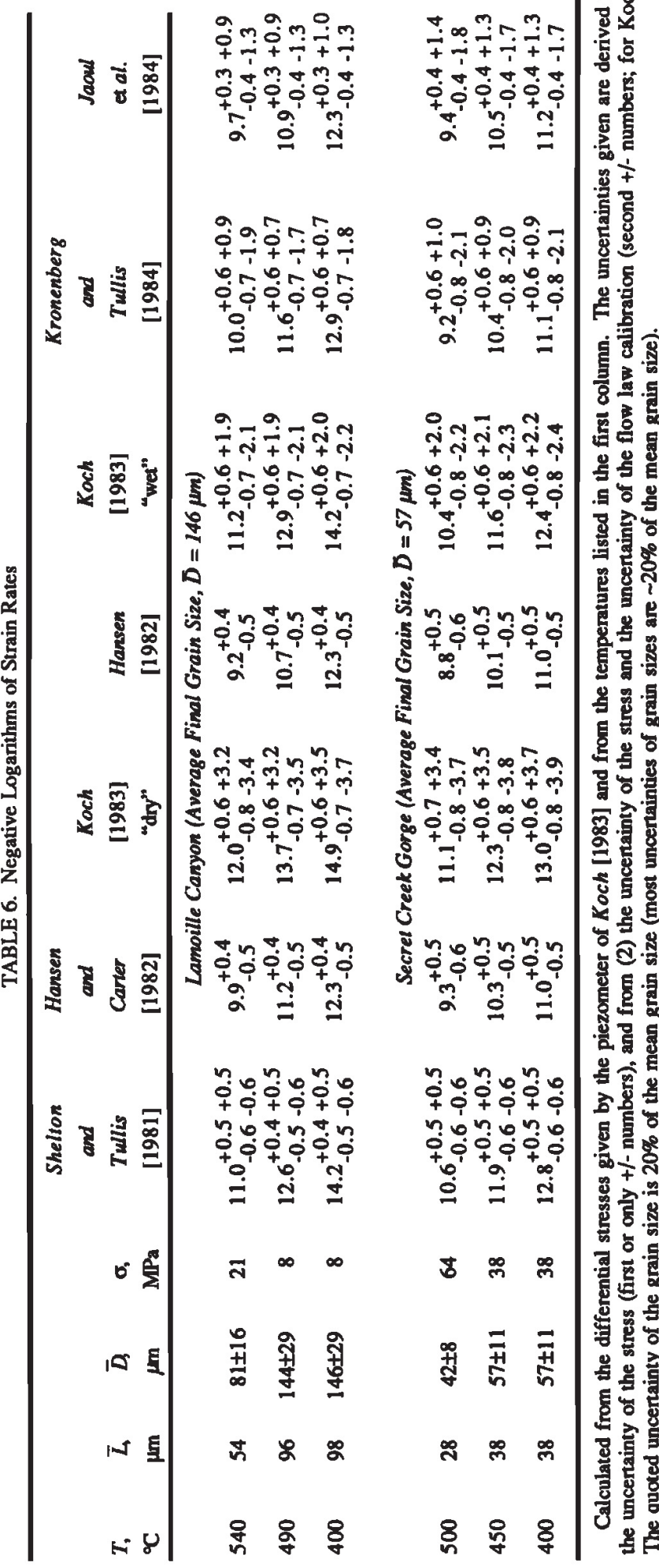

\begin{tabular}{|c|c|c|c|c|c|c|}
\hline \multirow{5}{*}{ 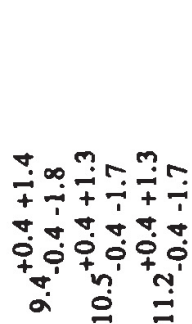 } & \multirow{5}{*}{ 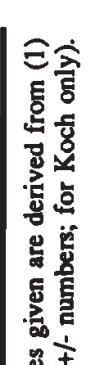 } & & \multicolumn{4}{|c|}{ Strain Rate, $\mathrm{s}^{-1}$} \\
\hline & & & $10^{-10}$ & $10^{-11}$ & $10^{-12}$ & $10^{-13}$ \\
\hline & & $\begin{array}{l}\text { Shear strain } \\
\text { rate, } \mathrm{s}^{-1} \\
\text { Thickness, m }\end{array}$ & $0.5 \times 10^{-10}$ & $0.5 \times 10^{-11}$ & $0.5 \times 10^{-12}$ & $0.5 \times 10^{-13}$ \\
\hline & & 1500 & 2250 & 225 & 23 & 2.3 \\
\hline & & 150 & 225 & 23 & 2.3 & 0.23 \\
\hline
\end{tabular}

Rates are $\mathrm{mm}_{\mathrm{rr}} \mathrm{r}^{-1}$ or $\mathrm{km} \mathrm{m} \cdot \mathrm{y}^{-1}$.

was homogeneous simple shear, we have calculated the possible range of shear-zone-parallel displacement rates (Table 7). For a strain rate of $10^{-12} \mathrm{~s}^{-1}$ and a mylonite zone thickness of $1.5 \mathrm{~km}$, the displacement rate parallel to the shear zone boundaries is $23 \mathrm{~mm} \mathrm{yr}^{-1}$ or $23 \mathrm{~km} \mathrm{m.y.}{ }^{-1}$. This rate is similar to the $16 \mathrm{~mm} \mathrm{yr}^{-1}$ rate estimated for the detachment fault system of the Whipple Mountains core complex based on field relations and geochronological constraints [Davis, 1988]. If the shear zone is thinner or thicker, then the displacement rate is respectively reduced or increased proportionately. For example, if the effective thickness of the shear zone is $150 \mathrm{~m}$, then a strain rate of $10^{-12} \mathrm{~s}^{-1}$ yields a displacement rate of 2.3 mm $\mathrm{yr}^{-1}\left(2.3 \mathrm{~km} \mathrm{m.y.} .^{-1}\right)$.

If we assume that the uplift of the mylonitic rocks occurred along a shear zone with constant dip that reached Earth's surface and rooted into the middle crust, we can calculate the uplift rate for rocks in the footwall from the fault-zone parallel displacement rate (Table 8). For example, if the displacement rate parallel to a shear zone dipping $15^{\circ}$ is $23 \mathrm{~mm} \mathrm{yr}^{-1}$, then the uplift rate of the footwall is $5.8 \mathrm{~mm} \mathrm{yr}^{-1}\left(5.8 \mathrm{~km} \mathrm{m.y.}{ }^{-1}\right)$. Similarly, the displacement rate parallel to the shear zone permits calculations of the horizontal extension rate (Table 8). For example, if the displacement rate parallel to a shear zone

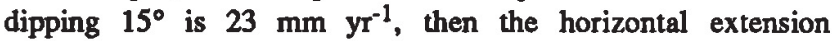
rate is $22 \mathrm{~mm} \mathrm{yr}^{-1}\left(22 \mathrm{~km} \mathrm{~m} . \mathrm{y} .^{-1}\right)$.

If we make the further assumption that the rate of uplift was constant through time, we can calculate the length of time required to bring the mylonitic rocks up to Earth's surface, because the peak pressure of mylonitization in the Ruby Mountains was $400 \pm 100 \mathrm{MPa}$ (Table 9 [Hurlow, 1988; H. Hurlow, personal communication, 1989]). Rocks mylonitized at $400 \mathrm{MPa}$ must have come from a depth of $\sim 15 \mathrm{~km}$ (assuming an average density of $2700 \mathrm{~kg} \mathrm{~m}^{-3}$ ). For example, if the uplift rate is $5.8 \mathrm{~mm} \mathrm{yr}^{-1}\left(5.8 \mathrm{~km}\right.$ m.y. $\left.{ }^{-1}\right)$, then the mylonitic rocks could have been lifted up $15 \mathrm{~km}$ in $2.6 \mathrm{~m} . \mathrm{y}$. For comparison, an uplift rate can also be calculated from ${ }^{40} \mathrm{Ar} /{ }^{39} \mathrm{Ar}$ and fission

TABLE 8. Displacement Rates for Inclined Fault Zones $1.5 \mathrm{~km}$ thick

\begin{tabular}{lrrrrr}
\hline Dip, & \multicolumn{5}{c}{ Fault Zone Parallel Displacement Rate } \\
\cline { 2 - 6 } deg & 2250 & 225 & 23 & 2.3 & 0.23 \\
\hline \multicolumn{5}{c}{ Uplift Rates } \\
30 & 1125 & 113 & 11.3 & 1.1 & 0.11 \\
15 & 582 & 58 & 5.8 & 0.58 & 0.058 \\
\multicolumn{5}{c}{ Horizonial Extension Retes } \\
30 & 1950 & 196 & 20 & 2.0 & 0.20 \\
15 & 2174 & 217 & 22 & 2.2 & 0.22 \\
\hline
\end{tabular}

Rates are $\mathrm{mm}_{\mathrm{yr}} \mathrm{r}^{-1}$ or $\mathrm{km}$ m.y..$^{-1}$. 
TABLE 9. Time Required to Lift Mylonitic Rocks From $15 \mathrm{~km}$ Depth to Earth's Surface

\begin{tabular}{cc}
\hline Vertical Displacement Rate, $\mathrm{mm} \mathrm{yr}^{-1}$ & Duration of Uplift, m.y. \\
\hline $39-75$ & $0.38-0.20$ \\
$3.9-7.5$ & $3.8-2.0$ \\
$0.39-0.75$ & $38-20$ \\
$0.039-0.075$ & $384-200$ \\
\hline
\end{tabular}

track data. Peak conditions of mylonitization $\left(630^{\circ} \mathrm{C}\right.$ and 400 $\mathrm{MPa}$ [Hurlow, 1988; H. Hurlow, personal communication, 1989]) indicate that the temperature at $15 \mathrm{~km}$ depth was $630^{\circ} \mathrm{C}$ and that the thermal gradient at that time averaged $42^{\circ} \mathrm{C} \mathrm{km}^{-1}$. The rocks now exposed in Lamoille Canyon cooled from $500^{\circ}$ to $70^{\circ} \mathrm{C}$ within $8 \mathrm{~m} . y$. at rates faster than $54 \pm 3^{\circ} \mathrm{C} \mathrm{m} \cdot \mathrm{y}^{-1}$ (see above discussion of ${ }^{40} \mathrm{Ar} /{ }^{39} \mathrm{Ar}$ and fission track data). If we assume that the cooling and decompression were linearly related to one another and constant through time, then the cooling was accompanied by uplift from $500^{\circ} \mathrm{C}$ at a depth of $11.8 \mathrm{~km}$ to $70^{\circ} \mathrm{C}$ at a depth of $1.2 \mathrm{~km}$ (equivalent to decompression from 312 to $32 \mathrm{MPa}$ ) at a rate of $1.33 \mathrm{~km}$ $\mathrm{m} . y .^{-1}$. This rate is the same order of magnitude as that calculated in the previous paragraph from piezometry and simple geometric arguments $\left(5.8 \mathrm{~km} \mathrm{m.y.}{ }^{-1}\right)$.

\section{SuMmary}

Quartzites from Secret Creek gorge and Lamoille Canyon in the Ruby Mountains have grain sizes of 91-151 $\mu \mathrm{m}$ and 42-64 $\mu \mathrm{m}$, respectively. The kinetic laws derived from grain-growth data of Tullis and Yund [1982] and Pierce [1987] indicate that mylonitization may have continued down to temperatures lower than $450^{\circ}-500^{\circ} \mathrm{C}$. Koch's [1983] quartz grain-size piezometer suggests that the mylonitization occurred at differential stresses of 38-64 MPa, or maximum shear stresses of 19-32 $\mathrm{MPa}$. Extrapolation of quartzite flow laws indicates that the mylonitization occurred at strain rates in the range $10^{-10}$ to $10^{-13} \mathrm{~s}^{-1}$ and probably within an order of magnitude of $10^{-12} \mathrm{~s}^{-1}$. These strain rates are compatible with displacement rates on the order of $23 \mathrm{~mm} \mathrm{yr}^{-1}$ for simple shear zones $1500 \mathrm{~m}$ thick. Such a shear zone dipping $15^{\circ}$ would produce uplift of footwall mylonitic rocks at a rate of $5.8 \mathrm{~km} \mathrm{~m} . \mathrm{y}_{-}^{-1}$ and a horizontal extension rate of $22 \mathrm{~km} \mathrm{m.y.}{ }^{-1}$. This uplift rate indicates that the mylonitic rocks could have been lifted up $15 \mathrm{~km}$ along a $15^{\circ}$-inclined shear zone in $2.6 \mathrm{~m} . \mathrm{y}$.

Our inferred differential stress data provide new constraints on the development of the Ruby Mountains metamorphic core complex, but whether these implications are applicable to other Cordilleran core complexes will remain unknown until more extensive data are available. Similar measurements in the Snake Range, Whipple Mountains, and Santa Catalina Mountains are in progress.

Acknowledgments. Two JGR reviewers provided helpful comments. This project was supported by University of California, Los Angeles, Academic Senate research funds awarded to An Yin; Art Snoke's recent field work was supported by NSF grant EAR-8707437.

\section{REFERENCES}

Avé Lallement, H. G., Subgrain rotation and dynamic recrystallization of olivine, upper mantle diapirism, and extension of the Basin-andRange province, Tectonophysics, 119, 89-117, 1985.

Avé Lallement, H. G., J. -C. Mercier, N. L. Carter, and J. V. Ross,
Rheology of the upper mantle: Inferences from peridotite xenoliths, Tectonophysics, 70, 85-113, 1980.

Bird, J. E., A. K. Mukherjee, and J. F. Dom, Correlations between high temperature creep behavior and structure, in Quantitative Relation Between Properties and Microstructure, edited by D. G. Brandon and R. Rosen, pp. 255-342, Israel Universities Press, Jenusalem, 1969.

Briegel, U., and C. Goetze, Estimates of differential stress recorded in the dislocation structure of Lochseiten limestone (Switzerland), Tectonophysics, 48, 61-76, 1978.

Bromley, R., and C. M. Sellars, High temperature deformation of copper and copper-aluminum alloys, in Microstructure and Design of Alloys, pp. 380-385, Institute of Metals, London, 1973.

Burg, J. P., C. Wilson, and J. C. Mitchell, Dynamic recrystallization and fabric development during simple shear deformation of ice, $J$. Struct. Geol., 8, 857-869, 1986.

Christie, J. M., and A. Ord, Flow stress from microstructures of mylonites: Example and current assessment, J. Geophys. Res., 85, 6253-6262, 1980.

Coney, P. J., and T. W. Harms, Cordilleran metamorphic core complexes: Cenozoic extensional relics of Mesoaoic compression, Geology, 12, 550-554, 1984.

Crittenden, M. D., Jr., P. J. Coney, and G. H. Davis, Cordilleran metamorphic core complexes, Mem. Geol. Soc. Am., 153. 490 pp., 1980.

Dallmeyer, R. D., A. W. Snoke, and E. H. McKee, The MesozoicCenozoic tectonothermal evolution of the Ruby Mountains, East Humboldt Range, Nevada: A Cordilleran metamorphic core complex, Tectonics, 5, 931-954, 1986.

Davis, G. A., Rapid upward transport of mid-crustal mylonitic gneisses in the footwall of a Miocene detachment fault, Whipple Mountains, southeastem California, Geol. Rundsch., 77, 191-209, 1988.

Davis, G. A., and G. S. Lister, Detachment faulting in continental extension: perspectives from the southwestern U.S. Cordillera, Spec. Pap. Geol. Soc. Am., 218, 133-159, 1988.

Davis, G. A., D. L. Martin, D. Krummenacher, E. G. Frost, and R. L. Armstrong, Geologic and geochronologic relations in the lower plate of the Whipple detachment fault, Whipple Mountains, southeastem California: A progress report, in Mesozoic-Cenozoic Tectonic Evolution of the Colorado River Region, California, Arizona, and Nevada, edited by E. G. Frost and D. L. Martin, pp. 408-432, Cordilleran Publishers, San Diego Calif., 1982.

Davis, G. A., G. S. Lister, and S. J. Reynolds, Structural evolution of the Whipple and South mountains shear zones, southwestem United States, Geology, 14, 7-10, 1986.

Dokka, R. K., M. J. Mahaffie, and A. W. Snoke, Thermochronologic evidence of major tectonic denudation associated with detachment faulting, northern Ruby Mountains-East Humboldt Range, Nevada, Tectonics, 5, 995-1006, 1986.

Dunning, G. H., M. A. Etheridge, and B. E. Hobbs, On the stress dependence of subgrain size, Textures Microstruct., 5, 127-152, 1982.

Dutham, W. B., C. Goetze, and B. Blake, Plastic flow of oriented single crystals of olivine, 2, Observations and interpretations of the dislocation structures, J. Geophys. Res., 82, 5755-5770, 1977.

Etheridge, M. A., and J. C. Wilkie, An assessment of dynamically recrystallized grainsize as a paleopiezometer in quartz-bearing mylonite zones, Tectonophysics, 78, 475-508, 1981.

Friedman, M., and N. G. Higgs, Calcite fabrics in experimental shear zones, in Mechanical Behavior of Crustal Rocks, Geophys. Monogr. Ser., vol. 24, edited by N.L. Carter et al., pp. 11-27, AGU, Washington, D.C., 1981.

Friedman, M., W. F. Dula, A. F. Gangi, and G. A. Guzonas, Subgrain size vs. stress in experimentally deformed synthetic rock salt, Eos Trans. AGU, 62, 397, 1981.

Frost, E. G., and D. L. Martin, Mesozoic-Cenozoic tectonic evolution of the Colorado River region, Califomia, Arizona, and Nevada, 608 pp., Cordilleran Publishers, San Diego, Calif., 1982.

Gans, P. B., An open-system, two-layer crustal stretching model for the eastem Great Basin, Tectonics, 6, 1-12, 1982.

Glover, G., and C. M. Sellars, Recovery and recrystallization during high temperature deformation of $\alpha$-iron, Metall. Trans., 4, 765$775,1973$.

Goetze, C., and D. L. Kohlstedt, Laboratory studies of dislocation climb and diffusion in olivine, J. Geophys. Res., 78, 5961, 1973.

Goetze, C., and D. L. Kohlstedt, The dislocation structures of 
experimentally deformed mable, Contrib. Mineral. Petrol., 59, 293-306, 1977.

Handin, J., J. E. Russell, and N. L. Carter, Experimental deformation of rocksalt, in Mineral and Rock Deformation: Laboratory Studies, Geophys. Monogr., Ser., vol. 36, edited by B.E. Hobbs and H.C Heard, pp. 117-160, AGU Washington, D.C., 1986.

Hansen, F. D., Semibrittle creep of selected crustal rocks at $1000 \mathrm{MPa}$ Ph. D. dissertation, 224 pp., Tex. A\&M Univ., College Station, 1982.

Hansen, F. D., and N. L. Carter, Creep of selected crustal rocks at 1000 $\mathrm{MPa}$, Eos Trans. AGU, 63, 437, 1982.

Harison, T. M., Diffusion of ${ }^{40} \mathrm{Ar}$ in homblende, Contrib. Mineral. Petrol., 78, 324-331, 1982.

Harrison, T. M., and I. McDougall, Excess ${ }^{40} \mathrm{Ar}$ in biotite: Temperature, pressure and compositional effects, Geochim. Cosmochim. Acta, 44, 1985-2003, 1985.

Heard, H.C., and N.L. Carter, Experimentally induced "natural" flow in quartz and quarzite, Am. J. Sci., 266, 1-42, 1968.

Howard, K. A., Paleozoic metasediments in the northern Ruby Mountains, Nevada, Geol. Soc. Am. Bull., 82, 259-264, 1971.

Howard, K. A., R. W. Kistler, A. W. Snoke, and R. Willden, Geological map of the Ruby Mountains, Nevada, scale 1:125,000, U.S. Geol. Surv., Misc. Invest. Ser., I-1136, 1979.

Hurlow, H. A., P-T conditions of mylonitization in a Tertiary extensional shear zone, Ruby Mountains-East Humboldt Range, Nevada, Geol. Soc. Am. Abstr. Programs, 20,170, 1988.

Jaoul, O., Sodium weakening of Heavitree Quartzite: Preliminary results, J. Geophys. Res., 89, 4271-4279, 1984.

Jaoul, O., J. A. Tullis, and A. K. Kronenberg, The effect of varying water contents on the creep behavior of Heavitree quartzite, $J$. Geophys. Res., 89, 4298-4312, 1984.

Kappmeyer, J., and D. V. Wiltschko, Quartz deformation in the Marguetta and Republic troughs, Upper Peninsula of Michigan, Can. J. Earth Sci., 21, 793-801, 1984.

Karato, S., Grain size distribution and rheology of the upper mantle, Tectonophysics, 104, 155-176, 1984.

Kirby, S.H., and A.K. Kronenberg, Rheology of the lithosphere, Rev. Geophys., 21, 1458-1487, 1983.

Kirby, S. H., and M. W. Wegner, Dislocation substructure of mantlederived olivine as revealed by selective chemical etching and transmission electron microscopy, Phys. Chem. Miner., 3, 309330, 1979.

Kistler, R. W., E. D. Ghent, and J. R. O'Neil, Petrogenesis of gamet two-mica granites in the Ruby Mountains, Nevada, J. Geophys. Res., 86, 10,591-10,606, 1981.

Koch, P. S., Rheology and microstructures of experimentally deformed quartz aggregates, Ph. D. dissertation, 464 pp., Univ. of Calif., Los Angeles., 1983.

Koch, P.S., J.M. Christie, A. Ord, and R.P. George Jr., Effect of water on the rheology of experimentally deformed quartzite, J. Geophys. Res., 94, 13,975-13,996, 1989.

Kohlstedt, D. L., and C. Goetze, Low-stress high-temperature creep in olivine single crystals, J. Geophys. Res., 79, 2045-2051, 1974.

Kohlstedt, D. L., and M. S. Weathers, Deformation-induced microstructures, paleopiezometers, and differential stresses in deeply eroded fault zones, J. Geophys. Res., 85, 6269-6285, 1980.

Kohlstedt, D. L., C. Goetze, and W. B. Durham, Experimental deformation of single crystal olivine with application to flow in the mantle, in Physical Chememistry of Minerals and Rocks, edited by R. G. J. Strens, pp. 35-49, John Wiley, New York, 1976.

Kohlstedt, D. L., R. F. Cooper, M. S. Weathers, and J. M. Bird, Paleostress analysis of deformation-induced micnostructures: Moine Thrust zone and Ikertoq shear zone, U.S. Geol. Surv. Open File Rep., 79-1239, 394-425, 1979.

Kronenberg, A. K., and J. Tullis, Flow strengths of quartz aggregates: Grain size and pressure effects due to hydrolytic weakening, $J$. Geophys. Res., 89, 4281-4297, 1984.

Linker, M. F., and S. H. Kirby, Anisotropy in the rheology of hydrolytically weakened synthetic quartz crystals, in Mechanical Behavior of Crustal Rocks, Geophys. Monogr. Ser., vol. 24, edited by N.L. Carter et al., pp. 29-48, AGU Washington, D.C., 1981.

Lister, G. S., and A. W. Snoke, S-C mylonites, J. Struct. Geol. 6, 617637, 1984.

Luton, M. J., and C. M. Sellars, Dynamic recrystallization in nickel and nickel-iron alloys during high temperature deformation, Acta Metall., 17, 1033-1043, 1969.

Mainprice, D. H., The experimental deformation of quartz polycrystals, Ph. D. dissertation. 171 pp., Aust. Nat. Univ., Canberra, Australia, 1981.

McCormick, J. W., Transmission electron microscopy of experimentally deformed synthetic quartz, Ph. D. dissertation, 171 pp., Univ. of Calif., Los Angeles, 1977.

Mercier, J.-C., Magnitude of the continental lithosphere stresses inferred from theomorphic petrology, J. Geophys. Res., 85, 62936303, 1980.

Mercier, J. C., D. A. Anderson, and N. L. Carter, Stress in the lithosphere: Inferences from steady-state flow of rocks, Pure Appl. Geophys., 115, 199-226, 1977.

Ord, A., and J. M. Christie, Flow stresses from microstructures in mylonitic quartzites of the Moine Thrust zone, Assynt area, Scotland, J. Struct. Geol., 6, 639-654, 1984.

Pierce, M. L., Kinetics of recovery and grain growth in hydrostatically annealed quartz aggregates, M. S. thesis, 116 pp., Univ. of Calif., Los Angeles, 1987.

Pierce, M. L., and J. M. Christie, Kinetics of grain growth in quartz aggregates, Eos Trans. AGU, 68, 422, 1987.

Poirier, J. -P., Creep of Crystals, 260 pp., Cambridge University Press, New York, 1985.

Post, R. L.., Jr., High-temperature creep of Mt. Bumet dunite, Tectonophysics, 42, 75-110, 1977.

Ranalli, G., Grain size distribution and flow stress in tectonites, $J$. Struct. Geol., 6, 443-447, 1984.

Ross, J. V., The nature and theology of the Cordilleran upper mantle of British Columbia: Inferences from peridotite xenoliths, Tectonophysics, 100, 321-357, 1983.

Ross, J. V., H. G. Avé Lallement, and N. L. Carter, Stress dependence of recrystallized grain and subgrain size in olivine, Tectonophysics, 70, 39-61, 1980a.

Ross, J. V., J. -C. Mercier, H. G. Avé Lallement, N. L. Carter, and J. Zimmerman, The Vourinos ophiolite complex, Greece: the tectonite suite, Tectonophysics, 70, 63-83, $1980 b$.

Ross, J. V., S. J. Bauer, and N. L. Carter, Effect of the $\alpha-\beta$ quartz transition on the creep properties of quartzite and granite, Geophys. Res. Lett., 10, 1129-1132, 1983.

Shelton, G., and J. A. Tullis, Experimental flow laws for crustal rocks, Eos Trans. AGU, 62, 396, 1981.

Simpson, C., Borrego Springs-Santa Rosa mylonite zone: A late Cretaceous west-directed thrust in southem California, Geology, 12, 8-11, 1984

Smith, C. S., and L. Guttman, Measurement of internal boundaries in three-dimensional structures by random sectioning, Trans. Am. Inst. Min. Metall. Pet. Eng., 197, 81-87, 1953.

Snoke, A. W., Transition from infrastructure to suprastructure in the northern Ruby Mountains, Mem. Geol. Soc. Am., 153, 287-333, 1980.

Snoke, A. W., and K. Howard, Geology of the Ruby Mountains-East Humboldt Range, Nevada: A Cordilleran metamorphic core complex, in Western Geologic Excursions, vol. 4, edited by J. Lintz, Jr., Pp. 260-303, 1984.

Snoke, A. W., and A. P. Lush, Polyphase Mesozoic-Cenozoic deformational history of the northern Ruby Mountains-East Humboldt Range, Nevada, in Western Geologic Excursions, vol. 4, edited by J. Lintz, Jr., pp. 232-260, 1984.

Snoke, A. W., and D. M. Miller, Metamorphic and tectonic history of the northeastem Great Basin, in Metamorphism and Crustal Evolution of the Western United States, edited by W. G. Emst, pp. 606-648, Prentice-Hall, Englewood Cliffs, N. J., 1988.

Tullis, J. A. and R. A. Yund, Growth kinetics of quartz and calcite aggregates, J. Geol., 90, 301-318, 1982.

Twiss, R. J., Theory and applicability of a recrystallized grain size paleopiezometer, Pure Appl. Geophys., 115, 227-244, 1977.

Twiss, R. J., Static theory of size variation with stress for subgrains and dynamically recrystallized grains, U.S. Geol. Surv. Open File Rep., 80-625, 665-683, 1980.

Valasek, P. A, A. W. Snoke, C. A. Hurich, and S. B. Smithson, Nature and origin of seismic reflection fabric, Ruby-East Humbold metamorphic core complex, Nevada, Tectonics, 8, 391-415, 1989.

Weathers, M. S., J. M. Bird, R. F. Cooper, and D. L. Kohlstedt, 
Differential stress determined from deformation-induced microstructures of the Moine Thrust zone, J. Geophys. Res., 84, 7496-7509, 1979.

Wegner, M. W., and J. M. Christie, Chemical etching of deformation substructures in quartz, Phys. Chem. Miner., 9, 67-78, 1983.

Wernicke, B. P., Low-angle normal faults in the Basin and Range province - nappe tectonics in an extending orogen, Nature, 291, 645-648, 1981.

Wernicke, B. P., Uniform-sense normal simple shear of the continental lithosphere, Can. J. Earth Sci., 22, 108-125, 1985.

Wright, J. E., and A. W. Snoke, Mid-Tertiary mylonitization in the Ruby Mountains-East Humboldt Range metamorphic core complex, Nevada, Geol. Soc. Am. Abstr. Programs, 18, 7959, 1986.

Zeuch, D. H., On the inter-relationship between grain size sensitive creep and dynamic recrystallization of olivine, Tectonophysics, 93 , 151-168, 1983.
Zeuch, D. H. and H. W. Green II, Experimental deformation of a synthetic dunite at high temperature and pressure, I, Mechanical behavior, optical microstructure and deformation mechanism, Tectonophysics, 110, 233-262, 1984.

J.M. Christie and A. Yin, Department of Earth and Space Sciences, UCLA, Los Angeles, CA 90024

B.R. Hacker,m Department of Geology, Stanford University, Satnford CA 94305

A.W. Snoke, Department of Geology and Geophysics, University of Wyoming, Laramie WY 82071

(Received June 21, 1989;

revised October 20, 1989;

accepted October 31, 1989.) 